\title{
Bagging time of 'Prata-anã' banana regarding anthracnose control
}

\author{
Martielle Batista Fernandes ${ }^{1}$, Edson Hiydu Mizobutsi ${ }^{2}$, Maria Luisa Mendes Rodrigues ${ }^{3}$, \\ Regina Cássia Ferreira Ribeiro ${ }^{2}$, Gisele Polete Mizobutsi ${ }^{2}$, Danilo Batista Pinho ${ }^{4}$
}

\begin{abstract}
The aim of this work was to determine the bagging time of 'Prata Anã' banana in order to reduce anthracnose disease. Treatments consisted of protection of banana bunches with TNT bags at emission, 30, 60, 90 and 120 days after emission and of unpacked bunches. Fruits were collected, stored in refrigeration chamber $\left(25 \pm 1{ }^{\circ} \mathrm{C}\right.$ and $\left.80 \pm 5 \% \mathrm{RH}\right)$ and evaluated for anthracnose incidence and severity. The study design was completely randomized with six treatments, repeated over two years. Data were submitted to analysis of variance and Tukey test ( $p$ $<0.05$ ). The physical and chemical characteristics of stored fruits were evaluated every three days for 12 days. The study design was completely randomized with six treatments, four evaluation periods, repeated over two years. Results were submitted to analysis of variance and regression $(\mathrm{p}<0.05)$. The anthracnose incidence was reduced by up to $67 \%$ by bagging bunches at emission. Bunches bagged at emission and at the first month of development did not show anthracnose severity. Bagging bunches reduces anthracnose incidence and severity. The bagging time does not interfere with the physical and chemical characteristics of fruits.
\end{abstract}

Index terms: Bagging, incidence and severity, post-harvest conservation.

\section{Época de ensacamento da banana 'Prata-anã' sobre o controle da antracnose}

Corresponding author: martiellefernandes@hotmail.com

Received: June 08, 2018

Accepted: November 30, 2018

Copyright: All the contents of this journal, except where otherwise noted, is licensed under a Creative Commons Attribution License.

\section{$(\mathrm{cc}) \mathbf{\mathrm { EY }}$}

\begin{abstract}
Resumo - O objetivo do trabalho foi determinar a época de ensacamento da banana 'Prata-Anã' visando a reduzir a doença antracnose. Os tratamentos consistiram na proteção dos cachos de banana com sacos de TNT na emissão de 30; 60; 90 e 120 dias após a emissão e de cachos não ensacados. Os frutos foram colhidos, armazenados em câmara de refrigeração $\left(25 \pm 1^{\circ} \mathrm{C}\right.$ e $80 \pm 5 \%$ UR) e avaliados quanto à incidência e a severidade da antracnose. O delineamento foi o inteiramente casualizado, com seis tratamentos, repetidos em dois anos. Os dados foram submetidos à análise de variância e teste de Tukey $(\mathrm{p}<0,05)$. As características físicas e químicas dos frutos armazenados foram avaliadas a cada três dias, por 12 dias. O delineamento foi o inteiramente casualizado, com seis tratamentos, quatro períodos de avaliação, repetidos em dois anos. Os resultados foram submetidos à análise de variância e regressão $(\mathrm{p}<0,05)$. A incidência da antracnose foi reduzida em até $67 \%$ pelo ensacamento dos cachos na emissão. Os cachos ensacados na emissão e no primeiro mês de desenvolvimento não apresentaram severidade da antracnose. O ensacamento na emissão dos cachos reduz a incidência e a severidade da antracnose. O período de ensacamento do cacho não interfere nas características físicas e químicas dos frutos.
\end{abstract}

Termos para indexação: Ensacamento, incidência e severidade, conservação pós-colheita.

\footnotetext{
${ }^{1}$ Agronomist PhD in Plant Production in the SemiArid, DCA / UNIMONTES. - Janaúba- MG, Brazil. E-mail: martiellefernandes@hotmail.com (ORCID 0000-0002-0797-4495)

${ }^{2} \mathrm{PhD}$. Professor - Department of Agrarian Sciences of Unimontes. Janaúba-MG, Brazil. E-mails: edson.mizobutsi@unimontes.br (ORCID 0000-

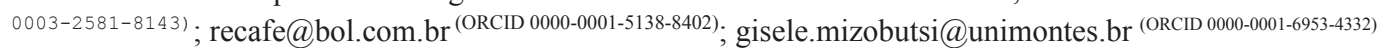

${ }^{3}$ Agronomist PhD student in Plant Production in the SemiArid, DCA / UNIMONTES. Janaúba-MG, Brazil. E-mail: marialuisamendes@yahoo. com.br (ORCID 0000-0002-7207-7299)

${ }^{4}$ Professor at the University of Brasília (UnB), Department of Phytopathology. Brasília-DF, Brazil. E-mail: danilopinho@unb.br (ORCID 00000003-2624-302X)
} 


\section{Introduction}

Several fungal diseases can occur in banana during the post-harvest phase. Among them, anthracnose, caused by Colletotrichum musae (Berk \& Curt.) von Arx, is responsible for great production losses of up to $40 \%$, affecting fruit quality (CORDEIRO et al., MIRSHEKARI et al., 2012). The importance of this disease is related to the frequency with which it appears, mainly, in domestic trade conditions in which little care is taken (COELHO et al., 2010).

The control of banana anthracnose is an essential post-harvest component of fruit quality (SAGOUA et al., 2011). The management strategies include mainly the use of fungicides (VILAPLANA et al., 2018); however, this type of control has caused damage to the environment and human health, and favors the emergence of resistant isolates (JINASENA et al., 2011). In addition, the use of post-harvest fungicides is increasingly limited. Fungicide prochloraz has been banned from the Brazilian market, further restricting available products. In this sense, there is a need to search for alternative methods of post-harvest disease control (BARBOSA et al., 2015).

Alternative methods such as physical barriers have been used by several producers to avoid pest damage in banana crops. This method has direct influence on anthracnose caused by C. musae in banana; however, few studies carried out on the ideal bagging period have been found in literature. According to Lichtemberg and Lichtemberg (2011), better results on the bagging of banana bunches are obtained when they are performed early, but they do not describe the ideal time for carrying out this practice. For Cavalin and Monteiro (2012), the bagging of bunches must be carried out together with the elimination of the banana's heart within two weeks after bunch emission. The authors recommend eliminating the last hand, aiming at the harvest of more homogeneous bunches. Thus, it is necessary to determine the bagging time of bunches to reduce post-harvest anthracnose.

Given the considerable post-harvest losses caused by C. musae in banana and the need for studies on factors related to the host that condition these losses, the aim of this work was to determine the bagging time of banana 'Prata Anã' cultivar to reduce infection by $C$. musae, without changes in the physical and chemical characteristics of the bagged fruit.

\section{Material and methods}

The experiment was implemented from April to September 2016 and repeated in the same period in 2017, in a commercial ' Prata Anã ' banana plantation area irrigated by the micro sprinkler system in Nova Porteirinha - MG ( $15^{\circ} 49^{\prime} \mathrm{S}, 43^{\circ} 16^{\prime} \mathrm{W}$, altitude of 540 masl, and Aw climate, according to Köppen classification).
In order to determine the bagging time of banana 'Prata Anã' cultivar to prevent or reduce C. musae infection, commercial TNT bags (polypropylene) with $0.80 \mathrm{~cm}$ in width by $1.30 \mathrm{~cm}$ in length and weight of $17 \mathrm{~g} / \mathrm{m}^{2}$, white in color were used. Treatments consisted of banana bunches bagged at different times (at bunch emission and 30, 60, 90 and 120 days after emission) and unpacked bunches. After 150 days of emission, bunches were harvested in a pre-climacteric stage, according to Von Loesecke's scale (PBMH and PIF, 2006), and bunches were selected for greater fruit uniformity. Leaves were transported to the Laboratory of Post-Harvest Pathology and subdivided into bouquets of three fruits. Bouquets were washed with neutral detergent and dried to ambient. After drying, bouquets were stored in trays of expanded polystyrene, identified by treatment and kept in refrigeration chamber $\left(25 \pm 1^{\circ} \mathrm{C}\right.$ and $\left.80 \pm 5 \% \mathrm{RH}\right)$. Disease intensity in fruits was evaluated by the anthracnose incidence and severity. Incidence was determined by the number of fruits infected per replicate, with values being expressed as percentage per treatment. To determine severity, the diagrammatic scale developed by Moraes et al. (2008) was used, with disease severity ranging from 0.5 to $64 \%$. The statistical design was completely randomized with six treatments and five replicates, each containing three fruits, repeated in two years. Results were submitted to analysis of variance and means were compared by the Tukey test $(p<0.05)$, using the Sisvar software.

The following physical and chemical characteristics were evaluated for the post-harvest preservation of bagged fruits: fruit length and diameter with the aid of pachymeter; loss of fresh fruit mass, with the aid of semi-analytical scale; firmness using CT3 $10 \mathrm{KG}$ texturometer, measured in the median region of the fruit with $25 \mathrm{~mm}$ long and 4 mm diameter tip; soluble solids using bench refractometer with reading in the 0 to $95^{\circ}$ Brix range, after extracting the pulp from the central region of each fruit; $\mathrm{pH}$, with digital $\mathrm{pH}$ meter model DM20, using $10 \mathrm{~g}$ of fruit pulp from the replicate set grinded and homogenized with $90 \mathrm{~mL}$ of distilled water; titratable acidity, according to technique recommended by AOAC (1992); bark color, determined by Color Flex 45/0(2200), stdz Mode: 45/0 colorimeter, with direct reflectance reading of $\mathrm{L} *$ (luminosity), a * (red or green) and $\mathrm{b} *$ (yellow and blue) coordinates of the Hunterlab Universal Software using the CIELAB scale with $10^{\circ} / \mathrm{D} 65$ illuminant, obtaining hue angle expressed in degrees, with $\mathrm{a} *$ and $\mathrm{b} *$ values and chromaticity by means of the formula: $\mathrm{C}=\left(\mathrm{a}^{2}+\mathrm{b}^{2}\right)^{0,5}$. The statistical design was completely randomized with six treatments, four evaluation periods, five replicates with three fruits each, repeated in two years. Results were submitted to analysis of variance and regression $(p<0.05)$ using the Sisvar software. 


\section{Results and discussion}

Values referring to the incidence of anthracnose in fruits submitted to bagging at different times are presented in Table 1. As there was no difference between the two years of evaluation for the incidence of anthracnose in fruits, the average of the evaluated period was used.

The bagging of 'Prata Anã' banana provided lower anthracnose incidence. The bagging of bunches at emission did not differ statistically from bagging carried out within 60 days after emission. The incidence of anthracnose in post-harvest fruits was observed at the time of harvest, demonstrating that banana is susceptible to C. musae infection in all periods. It could be observed that infection occurs during flowering or during floral differentiation and formation of bunches to be emitted. The floral differentiation is the point that indicates the end of the vegetative period and begins the process of fruiting, which after ceasing the production of leaf becomes the inflorescence that is organ of fruiting of the banana tree. (GUERRA, 2014).

There was higher anthracnose incidence in fruits submitted to bagging from 90 days after bunch emission, which also did not differ from unpacked fruits. A $47.33 \%$ disease incidence reduction in bunches bagged on the day of emission was evidenced, compared to bunches bagged at 120 days after emission and a $67 \%$ incidence reduction when compared to bunches without bagging protection in the field. Physical control techniques such as the bagging of banana bunches that aim to manipulate conditions to extend the disease-free period, are beneficial, but not sufficient for their complete protection against post-harvest infections (EL GHAOUTH et al., 2004). The bagging time directly influenced the incidence of postharvest anthracnose of 'Prata Anã' banana, indicating an increase in the percentage of diseased fruits as the bagging procedure was delayed. The initial bagging of bunches facilitates execution in the field and reduces the occurrence of the disease (LICHTEMBERG; LICHTEMBERG, 2011).

In the evaluation of the disease severity, results similar to those obtained for incidence were observed (Table 1). Bunches bagged up to 60 days after emission had lower anthracnose severity compared to bunches bagged after this period, although the highest severity, $0.58 \%$, was observed in unpacked fruits. The low percentage of disease severity can be explained by the fact that fruits were produced in the winter season, less favorable for the development of the disease, whose average temperature and rainfall values in this period were $22^{\circ} \mathrm{C}$ and $3 \mathrm{~mm}$, respectively. High anthracnose severity levels in fruits can occur in favorable meteorological conditions, with frequent rainfall, temperature and high relative air humidity (CACCIOLA et al., 2012). The protection of bunches with plastic packaging creates a microclimate favorable to the disease; however, the use of TNT reduces the ideal humidity conditions inside the packaging, disfavoring the germination of conidia. Increasing anthracnose severity values are observed as a function of the bagging period of bunches. This fact confirms the effect of the physical barrier in reducing the disease severity, since bunches in the first months of development have low anthracnose severity. The bagging of bunches reduces damage caused by disease, and provides fruits with better physical attributes (LICHTEMBERG;LICHTEMBERG, 2011).

There was no difference between the two years of evaluation for the physical and chemical characteristics of bagged fruits, thus the mean of evaluation periods was used. The mean fruit length and diameter values were $167.35 \mathrm{~mm}$ and $40.16 \mathrm{~mm}$, respectively. These variables did not present significant differences in relation to bagging and storage period. Regarding diameter, based on classification for 'Prata' banana (PBMH and PIF, 2006), the evaluated fruits fall under the category of extra or higher quality. Rodrigues et al. (2001) studied the influence of bagging on 'Prata Anã' banana and also did not observe significant effect of treatments on fruit length and diameter. These variables are important characteristics for the commercial classification of banana, being discarded when they do not reach appropriate length and diameter (SOTO BALLESTERO, 2008; DONATO et al., 2009).

For variable fresh weight loss, analysis of variance evidenced interaction between treatments and storage days $(p<0.05)$. Initially, on the first day of evaluation, bananas had mean weight of $345.72 \mathrm{~g}$, reducing to $282.14 \mathrm{~g}$ after 12 days of storage, an average loss of $18.39 \%$ of fresh matter mass (Figure 1-A). These results corroborate those found by Damatto Júnior et al. (2005), who evaluated 'Prata Anã' bananas after 12 days of storage and observed an increase in mass loss over the days from $4.25 \%$ on the third day to $20.4 \%$ on the twelfth day. Banana presents peaks of ethylene and $\mathrm{CO}_{2}$ production during the ripening process, which makes it very susceptible to post-harvest losses (SINGH et al., 2016; AHMED and PALTA, 2016).

In relation to fruit firmness as a function of days of storage and bagging of banana bunches, it was observed that values decreased linearly throughout the period, with similar behavior in all bagging times, thus without influence of treatment for this variable (Figure 1-B). At the beginning, mean firmness values of $30 \mathrm{~N}$ were obtained, reaching values close to zero at the end of the storage period. Santos et al. (2017) evaluated the conservation of 'Prata Anã' banana at 12 and $14^{\circ} \mathrm{C}$ and found firmness values similar to those obtained in this study, from 49.43 and $43.67 \mathrm{~N}$ on the first day of evaluation at 8.35 and $6.70 \mathrm{~N}$ at the end of the evaluation period, respectively. The ripening process of banana generates a series of physiological and biochemical changes in fruits, which include loss of pulp firmness, reduction of the starch content, resulting in an increase in the sugar content, as well as changes in fruit color and aroma, making fruits 
very perishable (NASCIMENTO JÚNIOR et al., 2008).

The soluble solids content also showed similar behavior in all treatments, with values increasing as a function of storage days, regardless of phenological stage in which bunches were bagged (Figure 1-C). In mature fruits, soluble solids content reached the end of the storage period $27^{\circ}$ Brix, on average. In work with protection of 'Prata' banana bunch, Euleuterio et al. (2010) obtained in fruits protected with green plastic bag, TNT and plastic bag + TNT, values close to those found in this work, with 20.8, 30 and $22.6^{\circ}$ Brix, respectively. Bananas undergo considerable changes in the sugar content after harvest due to the fact that they are climacteric fruit, being harvested before the beginning of ripening, with low sugar content. After harvesting, fruits are climatized and reach the climacteric respiratory peak, increasing sugar content during maturation (CHITARRA;CHITARRA, 2005).

For $\mathrm{pH}$, a reduction over the storage period from 5.5 to 6.1 on the third day of storage to 4.3 to 4.9 on the ninth day was observed, followed by an increase on the $12^{\text {th }}$ day of storage from 4.8 to 5.1 (Figure 1-D). Botrel et al. (2002) obtained similar pH values for 'Prata Anã' cultivar from 5.0 to 5.6 in green fruits and from 4.2 to 4.7 in mature fruits. In 'Prata' cultivar, Euleuterio et al. (2010) observed $\mathrm{pH}$ decrease according to ripening from 5.8 to 4.5 in bunches protected with TNT bags. According to Nascimento Junior et al. (2008), fruit $\mathrm{pH}$ values decrease after harvest, increasing at the end of ripening or beginning of senescence.

Titratable acidity in bagged fruits behaved inversely proportional to $\mathrm{pH}$ throughout the storage period. An increase in this variable was observed in all treatments according to banana maturation, from $0.25 \mathrm{~g}$ malic acid $100 \mathrm{~g}$ of pulp $\mathrm{p}^{-1}$ on the third day of storage to $0.56 \mathrm{~g}$ malic acid $100 \mathrm{~g}$ of pulp $\mathrm{p}^{-1}$ on the ninth day of storage, followed by decreasing on the twelfth day to $0.45 \mathrm{~g}$ malic acid $100 \mathrm{~g}$ of pulp ${ }^{-1}$ (Figure 2-A). Euleuterio et al. (2010) also did not verify interference in acidity in relation to the use or not of the physical protection. The main organic acid found in bananas is malic acid. The fruit has low acidity characteristic at the beginning of ripening, and as it matures, acidity slowly increases and then decreases in the mature phase (DURIGAN; RUGGIERO, 1995).

For fruit coloring, it was observed that the luminosity value $\left(\mathrm{L}^{*}\right)$ of banana bark ranged from 57 to 63 and from 55 to 61 in fruits on the third day of storage and at 12 days, respectively. These values increased until the seventh day, between 65 and 69 , with a decrease in luminosity at the end of storage in all treatments, showing fruit ripening and subsequent senescence (Figure 2-B). Luminosity represents fruit brightness, ranging from 0 (fruit without brightness) to 100 (bright fruit). According to Silva et al. (2007), 'Nanica' bananas stored for zero, 14 and 32 days showed luminosity of 53.86; 53.97 and 43.47 , respectively, and these values are lower than those presented in this study. The bagging of bunches produces fruits with better coloration, softness and brightness (LICHTEMBERG;LICHTEMBERG, 2011).

During storage, it was observed that there was an increase in chromaticity values, which expresses the bark color intensity, followed by reduction on the last day of storage, indicating that there was no browning of fruits until the beginning of senescence. For all treatments, color intensity increased from the third day from 39 to 44 to 45 to 49 on the twelfth day of storage (Figure 2-C). Castricini et al. (2015) analyzed the chromaticity of mature 'Prata Anã' banana bark and found average values of 53.32 when stored at $25^{\circ} \mathrm{C}$.

It could be seen in figure 2-D that the bark hueangle values decreased during storage from 97 to $100^{\circ}$ to 72 to $75^{\circ}$. These results reveal the evolution of the banana bark color shade from green to yellow. Coloring is the most attractive quality attribute for the consumer, because it is one of the main criteria for the identification of fruit ripenig (CHITARRA;CHITARRA, 2005).

Table 1. Incidence (\% of infected fruits) and severity (\% of infected fruit area) of anthracnose in 'Prata Anã' banana submitted or not to bagging at different periods. Average two years of evaluations.

\begin{tabular}{lcc}
\hline \multicolumn{1}{c}{ Treatments } & Incidence $(\%)^{*}$ & Severity $(\%)^{*}$ \\
\hline Bagging at bunch emission & $11.00 \mathrm{a}$ & $0.00 \mathrm{a}$ \\
Bagging at 30 DAE** & $16.50 \mathrm{a}$ & $0.00 \mathrm{a}$ \\
Bagging at 60 DAE & $33.25 \mathrm{a}$ & $0.08 \mathrm{a}$ \\
Bagging at 90 DAE & $58.25 \mathrm{~b}$ & $0.50 \mathrm{~b}$ \\
Bagging at 120 DAE & $58.33 \mathrm{~b}$ & $0.42 \mathrm{~b}$ \\
No bagging & $77.75 \mathrm{~b}$ & $0.58 \mathrm{~b}$ \\
\hline \multicolumn{1}{c}{ VC $(\%)$} & 47.67 & 27.67 \\
\hline
\end{tabular}

* Means followed by the same letter in the column do not differ by the Tukey test $(\mathrm{p}<0.05)$.

$* * \mathrm{DAE}=$ Days after bunch emission. 


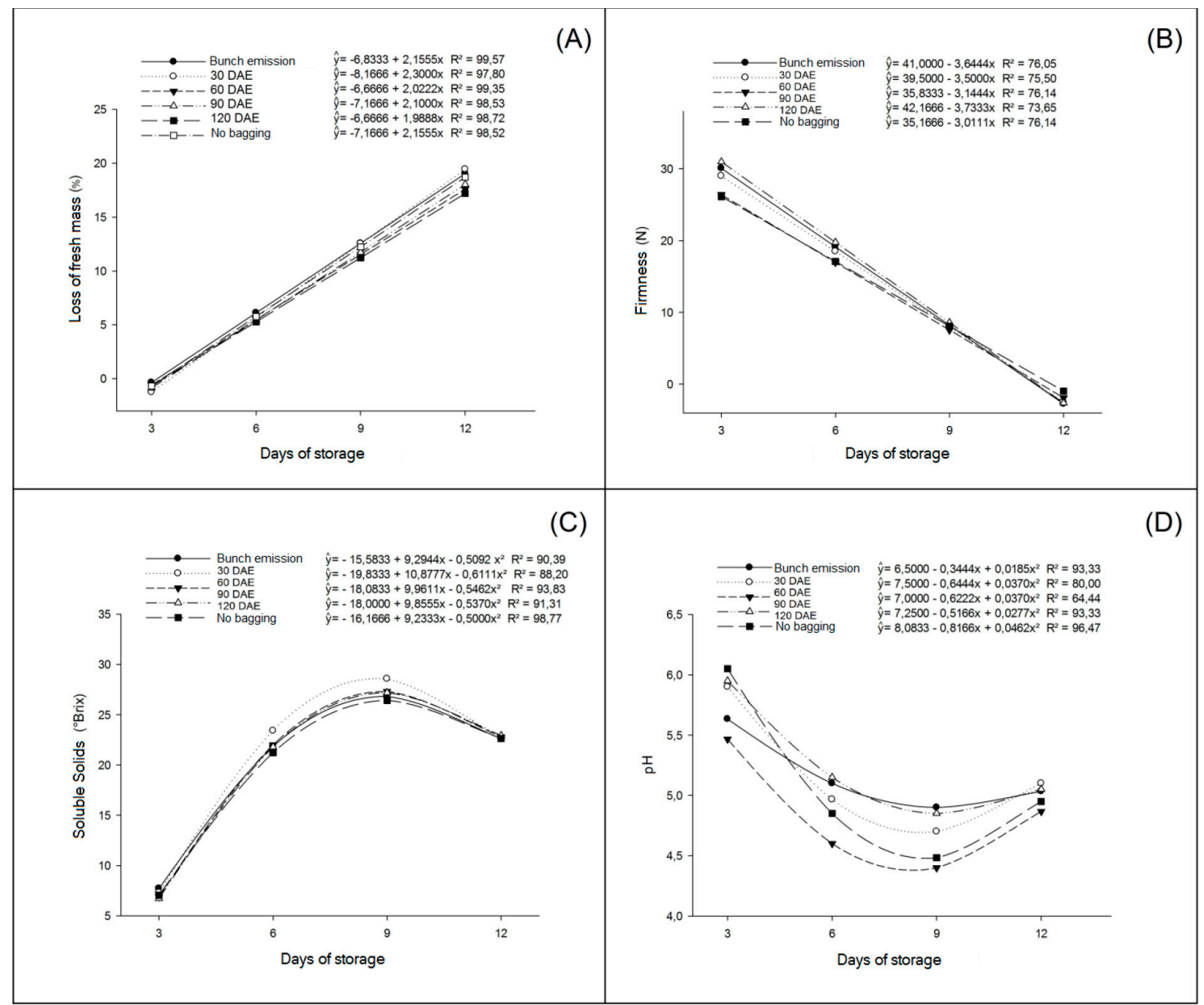

Figure 1. Loss of fresh mass (A), firmness (B), soluble solids (C) and $\mathrm{pH}(\mathrm{D})$ as a function of days of storage and bagging of 'Prata Anã' banana bunches with TNT bags at different periods. 


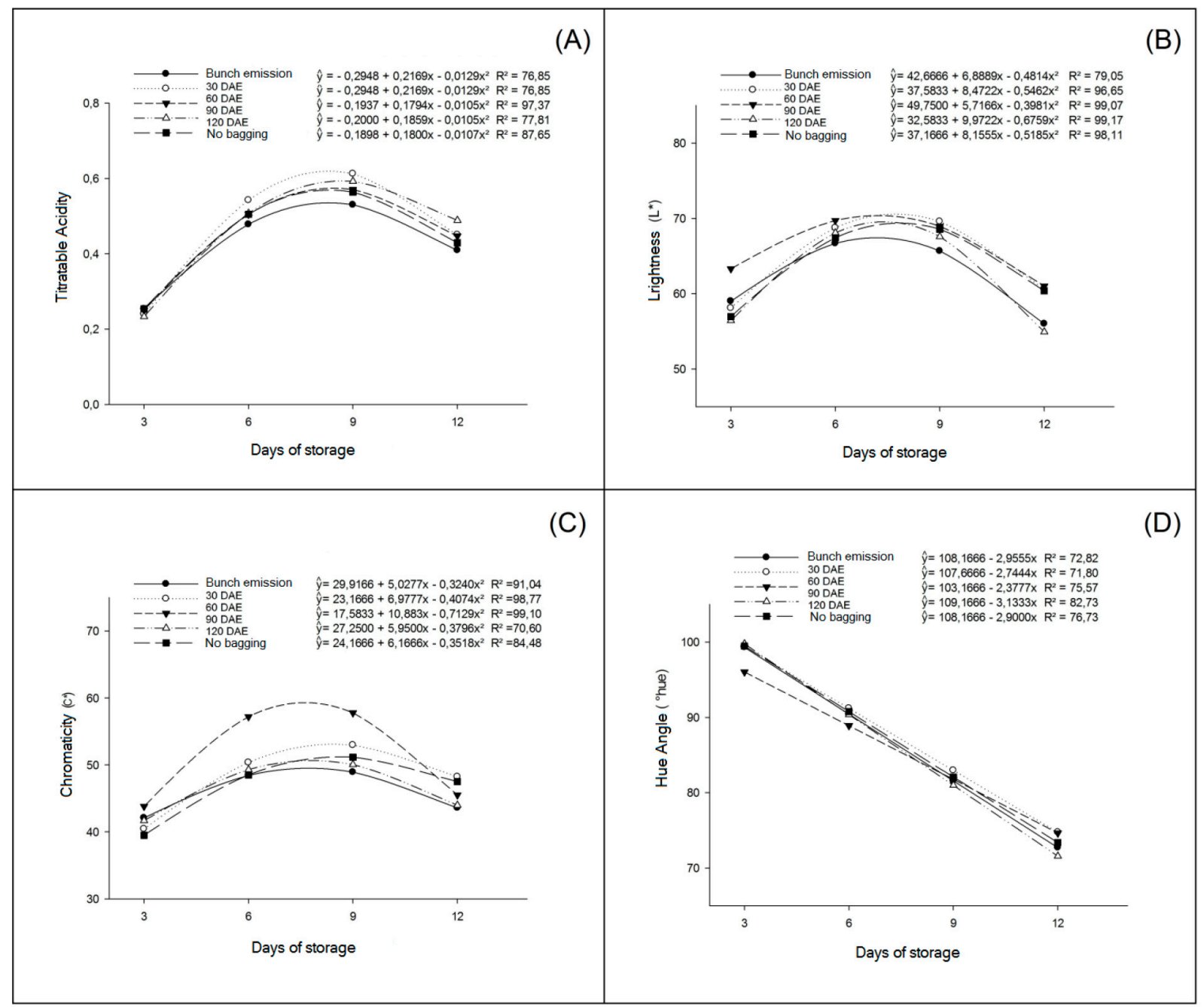

Figure 2. Titratable acidity (A), brightness (B), chromaticity (C) and hue angle (D) as a function of days of storage and bagging of 'Prata Anã' banana bunches with TNT bags at different periods.

\section{Conclusions}

Bagging of 'Prata Anã' bananas with TNT bags significantly reduces the incidence and severity of postharvest anthracnose.

The bagging time does not significantly interfere with the physical and chemical characteristics of 'Prata Anã’ banana.

\section{Acknowledgments}

To the Foundation for Research Support of the State of Minas Gerais - FAPEMIG and CAPES for the indispensable financial support to carry out the work.

\section{References}

AHMED, Z.F.R.; PALTA, J.P.Postharvest dip treatment with a natural lysophospholipid plus soy lecithin extended the shelf life of banana fruit. Postharvest Biology and Tecnology, Auckland, v.113, n.3, p.58-65, 2016.

AOAC. Official methods of analysis of the Association of Official Analytical Chemistry. 11 ed. Washington: AOAC, 1992. $1115 \mathrm{p}$.

BARBOSA, M. S.; VIEIRA, G. H. C.; TEIXEIRA, A.V. Atividade biológica in vitro de própolis e óleos essenciais sobre o fungo Colletotrichum musae isolado de bananeira (Musa spp.). Revista Brasileira de Plantas Medicinais, Botucatu, v.17, n.2, p.254-261, 2015. 
BOTREL, N.; FREIRE JUNIOR, M.; VASCONCELOS, R. M. de; BARBOSA, H. T. G. Inibição do amadurecimento da banana 'Prata-anã' com a aplicação do 1-metilciclopropeno. Revista Brasileira de Fruticultura, Jaboticabal, v.24, n.1, p.53- 56, 2002.

CACCIOLA, S.O.; FAEDDA, R.; SINATRA, F.; AGOSTEO, G.E.; SCHENA, L.; FRISULlO, S.; MAGNANO DI SAN LIO, G. Olive anthracnose. Journal of Plant Pathology, Pisa, v.94, n.1, p. 29-44, 2012.

CASTRICINI, A.; SANTOS, L. O.; DELIZA, R.; COELHO, E. F.; RODRIGUES, M. G. V. Caracterização pós-colheita e sensorial de genótipos de bananeiras tipo prata. Revista Brasileira de Fruticultura, Jaboticabal, v.37, n.1, p.27-37, 2015.

CAVALIN, M. O.; MONTEIRO, J. M. G. Boas práticas agrícolas recomendadas para o cultivo de banana na comunidade do Faraó em Cachoeiras de Macacu, RJ. Rio de Janeiro: Embrapa Solos, 2012. 38 p.

CHITARRA, M.I.F.; CHITARRA, A.B. Pós-colheita de frutos e hortaliças: fisiologia e manuseio. Lavras: UFLA, 2005. 785p.

COELHO, A. F. S.; DIAS, M. S. C.; RODRIGUES, M. L. M.; LEAL, P. A. M. Controle pós-colheita da antracnose da banana 'Prata- Anã' tratada com fungicidas e mantida sob refrigeração. Ciência e Agrotecnologia, Lavras, v.34, n.4, p.1104-1108, 2010.

CORDEIRO, Z.L.M.; MATOS, A.P.; KIMATI, H. Doenças da bananeira. In: KIMATI, H.; AMORIM, L.; BERGAMIN FILHO, A.; CAMARGO, L.E.A.; REZENDE, J.A.M. (Ed.). Manual de fitopatologia: doenças das plantas cultivadas. 4.ed. São Paulo: Agronômica Ceres, 2005. cap. 15. v.2, p.99-117.

DAMATTO JUNIOR, E. R.; CAMPOS, A. J. DE; MANOEL, L.; MOREIRA, G. C.; LEONEL, S.; EVANGELISTA, R. M. Produção e caracterização de frutos de bananeira 'Prata-Anã' e 'Prata-Zulu'. Revista Brasileira de Fruticultura, Jaboticabal, v.27, n.3, p.440443, 2005.

DONATO, S. L. R.; ARANTES, A. M.; SILVA, S. O.; CORDEIRO, Z. M. Comportamento fitotécnico da bananeira 'Prata-Anã' e de seus híbridos. Pesquisa Agropecuária Brasileira, Brasília, DF, v. 44, n. 12, p.1608-1615, 2009.

DURIGAN,J.F.; RUGGIERO, C. Bananas de qualidades. Jaboticabal: FUNEP, 1995. 37p.
EL GHAOUTH, A., DROBY, S.; WILSON, C.L.; WISNIEWSKI, M.; SMILANICK, J.; KORSTEN, L. Biological control of postharvest diseases of fruits and vegetables. In: KHACHATOURIANS, G.G., ARORA, D.K. (Ed.). Applied mycology and biotechnology: agriculture and food production. Amsterdam: Elsevier Science, 2004. p. 11-27.

EULEUTERIO, M. D.; GIOPPO, M.; SOZIM, M.; MALGARIM, M. B. Avaliação das características físicoquímicas de bananas prata (Musa AAB subgrupo Prata) ensacadas em diferentes tipos de materiais. Revista de Engenharia e Tecnologia, Ponta Grossa, v.2, n.1, p.49$56,2010$.

GUERRA, A. G. Agronegócio da banana. Natal: EMPARN, 2014.181p.

J INASENA, D.; PAT H IRATHNA, P. ; WICKRAMARACHCHI, S.; MARASINGHE, E. Use of chitosan to control anthracnose on "Embul" banana. In: INTERNATIONAL CONFERENCE ON ASIA AGRICULTURE AND ANIMAL, 2011. Anais... Singapoore: IACSIT Press, 2011. p.101-107.

LICHTEMBERG, L. A.; LICHTEMBERG, P. dos S. F. Avanços na bananicultura brasileira. Revista Brasileira de Fruticultura, Jaboticabal, v.33, n.1, p.29-36, 2011. Número especial.

MIRSHEKARI, A.; DING, P.; KADIR, J.; GHAZALI, H.M. Effect of hot water dip treatment on postharvest anthracnose of banana var. Berangan. African Journal of Agricultural Research, Nairobi, v.7, n.1, p. 6-10, 2012.

MORAES, W. S.; ZAMBOLIM, L.; LIMA, J. D. Quimioterapia de banana 'Prata anã' no controle de podridões pós-colheita. Arquivos do Instituto Biológico, São Paulo, v.75, n.1, p.79-84, 2008.

NASCIMENTO JUNIOR, B.B.; OZORIO, L.P.; REZENDE, C.M.; SOARES, A.G.; FONSECA, M.J.O. Diferenças entre bananas de cultivares Prata e Nanicão ao longo do amadurecimento: características físico-químicas e compostos voláteis. Ciência e Tecnologia de Alimentos, Campinas, v.28, n.3, p.649-658, 2008.

PBMH e PIF. Programa Brasileiro para a Modernização da Horticultura \& Produção Integrada de Frutas. Normas de classificação de banana. São Paulo: CEAGESP, 2006. [Documentos, 29]. 
RODRIGUES, M.G.V.; SOUTO, R.F.; MENEGUCCI, J.L.P. Influência do ensacamento do cacho na produção de frutos da bananeira 'prata-anã' irrigada, na região Norte de Minas Gerais. Revista Brasileira de Fruticultura, Jaboticabal, v. 23, n. 3, p.559-562, 2001.

SAGOUA, W. DUCAMP, M. N.; LOISEAU, G.; LAPEYRE De BELLAIRE, L. de. Effect of lactoperoxidase system on the control of Colletotrichum musae on bananas. Food Technology Biotechnology, Zagreb, v.49, n.2, p.244-248, 2011.

SANTOS, L..; MARTINS, R.N.; CASTRICINI, A.; RODRIGUES, M.G.V.; DIAS, M.S.C. 'Prata-Anã' banana conservation at $12{ }^{\circ} \mathrm{C}$ and $14^{\circ} \mathrm{C}$ under controlled atmosphere. Científica, Jaboticabal, v.45, n.1, p.57-63, 2017.
SILVA, S. F.; DIONÍSIO, A. P.; WALDER, J. M. M. Efeitos da radiação gama em banana "Nanica" (Musa sp., grupo AAA) irradiada na fase pré-climatérica. Alimentos e Nutrição, Araraquara, v.18, n.3, p.331$337,2007$.

SINGH, B.; SINGH, J.P.; KAURB, A.; SINGH, N. Bioactive compounds in banana and their associated health benefits - A review. Food Chemistry, Amsterdam, v.206, n.6, p.1-11, 2016.

SOTO BALLESTERO, M. Bananos: técnicas de produción, poscosecha y comercialización. 3.ed. San José: Litografía e Imprenta Lil, 2008.

VILAPLANA, R.; PAZMIÑO, L.; VALENCIACHAMORRO, S. Control of anthracnose, caused by Colletotrichum musae, on postharvest organic banana by thyme oil. Postharvest Biology and Technology, Auckland, v.138, n. 1 p. 56-63, 2018. 